\title{
Analysis of learning theories for the creation of a methodology for inclusion in universities in Mexico
}

\section{Análisis de teorías de aprendizaje para la elaboración de una metodología para la inclusión en las universidades en México}

MOTA-BARRAGÁN, Martha Elba †*, MENDIOLA-GARCÍA, Yessica, MARTÍNEZ-AGUILAR, Gloria Mónica and MORALES-IBARRA, Vanessa Maribel

Universidad Tecnológica de Torreón. Carretera Torreón-Matamoros s/n ejido El Águila. CP. 27087

ID $1^{\text {st }}$ Author: Martha Elba, Mota-Barragán / ORC ID: 0000-0002-7994-0841, CVU CONACYT ID: 973093

ID $1^{\text {st }}$ Coauthor: Yessica, Mendiola-García / ORC ID: 0000-0002-5387-5965, CVU CONACYT ID: 599221

ID $2^{\text {nd }}$ Coauthor: Gloria Mónica, Martínez-Aguilar / ORC ID: 0000-0003-3834-4880, Researcher ID Thomson: G-38782018, CVU CONACYT ID: 213558

ID $3^{\text {rd }}$ Coauthor: Vanessa Maribel, Morales-Ibarra / ORC ID: 0000-0003-3764-8858, Researcher ID Thomson: F-52872018, CVU CONACYT ID: 387893

DOI: $10.35429 /$ EJC.2019.9.5.25.31

Received September 18, 2019; Accepted December 30, 2019

\begin{abstract}
In recent years, inclusion in Mexico has caused higher education institutions to open their doors to people with disabilities who want to access an education program. Taking into account that the word include is bound to accept, it is important to have the appropriate knowledge, tools, spaces, and attitudes for the reception of these people in campuses, both private and public, to achieve a synergy among all the involved in the binomial teachinglearning. All this with the objective of strengthening inherent competencies of people with disabilities and granting others in order to let them compete in the chosen institution. In this document, different learning theories will be analyzed, in order to know their strengths and suggest a methodology that allows teacher and student to be aware of their inherent competences as well as know the ones needed to have a good performance in the class. Through a concept map that describes the key points of the aforementioned theories to reach the final result. It should be noted that until now there is little information regarding the study of a specific practice for the inclusion of people with disabilities in higher education in Mexico. For this reason, this analysis is relevant.
\end{abstract}

Inclusion, Disabilities, Methodology

\section{Resumen}

La inclusión en México en los últimos años ha generado que la educación superior ofrezca puertas abiertas a las personas con discapacidades que quieran acceder a una carrera. Teniendo en cuenta que la palabra incluir está ligada a aceptar, son necesarios los conocimientos, herramientas, espacios y actitudes adecuadas para el recibimiento de estas personas en escuelas, tanto privadas como públicas, para lograr una sinergia entre los involucrados en el binomio enseñanza-aprendizaje, para potencializar las competencias inherentes de las personas con discapacidades y otorgarle otras que puedan hacerlo competitivo en la institución elegida. En este escrito se analizarán diferentes teorías de aprendizaje, para formar una metodología que permita al docente y al alumno conocer las competencias con las que ya cuentan y estar consciente de las que requieren para su desempeño en el aula. Dicha metodología se describirá, en este documento, mediante un mapa conceptual que describirá los puntos clave de las teorías mencionada para llegar al resultado final. Cabe señalar que hasta este momento hay poca información referente al estudio de una metodología específica para la inclusión de las personas con discapacidades en la educación superior en México. Por esta razón el análisis en cuestión resulta pertinente.

Inclusión, Discapacidades, Metodología

Citation: MOTA-BARRAGÁN, Martha Elba, MENDIOLA-GARCÍA, Yessica, MARTÍNEZ-AGUILAR, Gloria Mónica and MORALES-IBARRA, Vanessa Maribel. Analysis of learning theories for the creation of a methodology for inclusion in universities in Mexico. Journal-Republic of Colombia. 2019. 5-9: 25-31

$\uparrow$ Researcher contributing as first author. 


\section{Introduction}

The issue of inclusion in universities in Mexico has increased in recent years because of technological advances in different fields such as media, which facilitate access to information. This has allowed us to offer educational options in institutions that are inclusive, from preschool to higher education. However, it is necessary to accept that in the latter, despite having professors, teachers or doctors, the inclusion of students with disabilities is not always an easy task, since sometimes the capacities of these students are unknown, as well as the different types of learning that allow teachers to choose the appropriate teaching methods, didactics and learning environments for their groups.

For this reason, an analysis of different learning theories is necessary, so that through their characteristics, the appropriate options for the elaboration of a methodology can be identified, enabling the teacher an orderly structure of teaching techniques, activities or tasks that can be assigned to students with hearing, visual and motor disabilities. In the same way, the student will have the opportunity to enhance their existing abilities and feel included in the class.

The theories suggested for the analysis are the following: Cognitive Psychology, Constructivism, Sociocultural Theory, Multiple Intelligences, Learning and Skills of the 21st century.

In this document the analysis of the main characteristics of each theory is presented, based on the disabilities mentioned above, to later suggest a methodology that allows teachers to have different options in terms of design and preparation of their classes, learning environments and educational technologies to use, as well as their main objective: to include all the participants in the classroom in the development of the teaching-learning process.

\section{Learning theories}

Below are the learning theories described and analyzed to observe their application in a suggested methodology.

\section{Cognitive psychology}

Cognitive psychology can be defined as the branch of psychology that attempts to provide a scientific explanation of how the brain performs complex mental functions such as vision, memory, language and thought. Cognitive psychology emerged at a time when computers began to have a great impact on science and, probably, it was natural for cognitive psychologists to establish an analogy between computers and the human brain. Different authors who study this theory tend to compare the human brain with a computer, which performs different functions such as storage, data processing and interpretation, memory and language.

Cognitive psychology is the study of the mental processes that enable our daily development in the recognition of familiar objects and people, management of the world around us, including the skills of reading, writing, programming, making plans, thinking, making decisions and memorizing what has been learned. The field of application in education involves the measurement of intellectual capacity, vocational guidance, learning problems, etc. but, above all, learning and teaching in the classroom, processes that involve considering intrapersonal variables (cognitive structure, evolutionary development, motivations, attitudes and personality of the students), as well as situational variables (didactic, social, academic, among others).

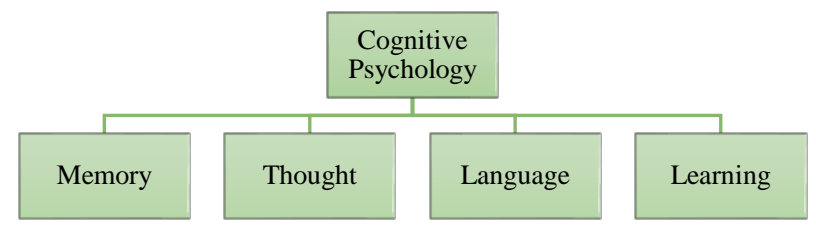

Figure 1 Conceptual framework of Cognitive Psychology Theory

Prepared by the authors

\section{Constructivism}

This theory describes learning as the construction of knowledge based on previous learning, that is, knowledge is built based on what was previously acquired. This theory suggests that the acquisition of knowledge is a continuous and active mental process and that although it is an individual activity, it is important to do collaborative work since the student will learn more effectively in this way. 
It is also important to mention that learning, in this theory, suggests that the student generates the concepts of new information by relating it to what he already possess, thus transforming the acquisition of the concepts into Meaningful Learning. In that sense, it is suggested that the students learn at their own pace, monitored by the teachers who play a mediator role between themselves and the activities that lead students to the acquisition of knowledge.

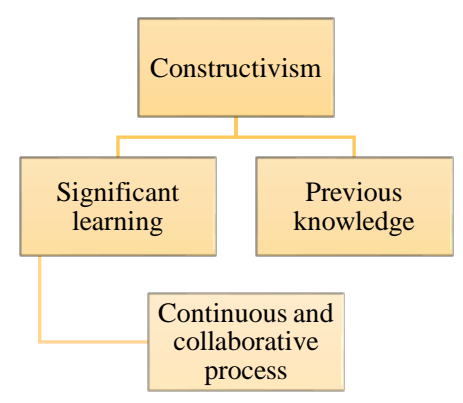

Figure 2 Conceptual framework of Constructivism Theory

Prepared by the authors.

\section{Sociocultural Theory}

This theory focuses on children's learning and emphasizes their active participation in the environment that surrounds them, having as response the cognitive development acquired collaboratively. According to Lev Vigotsky (Russia, 1896-1934), the role of adults or more advanced classmates is the support, direction and organization of student learning, in the previous step that they may be able to master, having internalized the behavioral and cognitive structures that the activity demands.

This orientation is more effective in offering children help to cross the Zone of Proximal Development (ZPD), which can be understood as the space between what children are already able to do and what they still cannot achieve on their own, but with the right help and guidance, they are able to perform the task successfully. According to this theory, as long as collaboration, supervision and responsibility for learning are covered, the individual progresses adequately in the formation and consolidation of their new knowledge and learning.

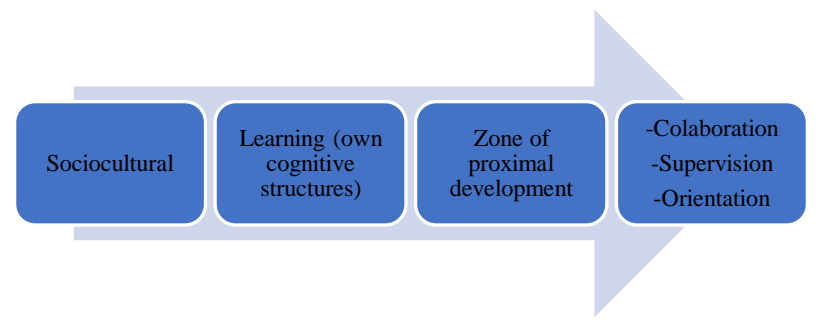

Figure 3 Conceptual framework of Sociocultural Theory Prepared by the authors

\section{Multiple intelligences}

This theory suggests that there are eight types of intelligence that determine the way in which people acquire knowledge. It points out that all people possess intelligence, but that they may have certain characteristics that classify them differently. That is, if the person dominates the characteristics of one or other intelligence, it will be easier to acquire knowledge and learn. The different intelligences according to Howard Gardner (1983) are the following:

Linguistic intelligence: it allows the individual to communicate clearly and precisely, not only orally, but also in a written or gestural manner.

- Logical-mathematical intelligence: it includes the capacity for logical reasoning and the resolution of mathematical problems. The speed to solve these problems is the indicator that determines how much logicalmathematical intelligence a person possess.

- Spatial intelligence: Also known as visual-spatial intelligence, it is the ability to observe the world and objects from different perspectives. People who possess this intelligence can devise mental images, define details and have a taste for aesthetics that gives them a personal sense.

- Musical intelligence: for some people with this type of intelligence, certain areas of the brain perform functions related to the interpretation or composition of music and can be trained or perfected.

- Body and kinesthetic intelligence: it comprises the skills to handle tools, as well as those that use the body for the expression of feelings or the creation of objects. This category includes dancers, actors, athletes, surgeons and plastic artists. 
- Intrapersonal Intelligence: it is the intelligence that allows individuals to have power and control over their emotions and search within themselves the reasons that make them be what they are. This type of intelligence makes the person work better individually and be alert of negative situations in order to keep their distance if necessary.

Interpersonal Intelligence: this type of intelligence allows the person to have an easy relationship with others, as well as interpret words or gestures and notice things that their other senses cannot. People who own it are able to work with very large groups.

Naturalist Intelligence: it is based on the classification and differentiation of the various aspects of the environment, such as natural phenomena, animal and plant species, as well as climatological and geographical events.

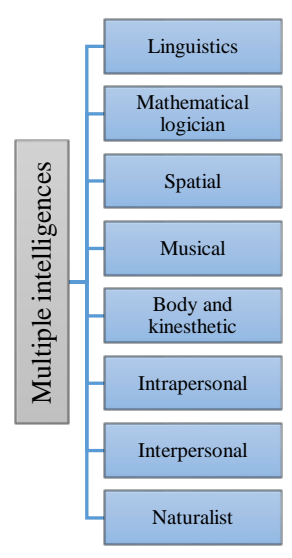

Figure 4 Conceptual framework of Multiple Intelligence theory

Prepared by the authors

\section{Learning and Skills of the 21st Century}

For the Organization for Economic Co-operation and Development (OECD), this type of education is based on the use of skills and competences working together with the technological advances that facilitate the development of tasks. It focuses on issues of the 21 st century (global awareness, civic literacy, health education, environment, financial literacy, business and business literacy); learning and innovation skills (creativity and innovation, critical thinking and problem solving, communication and collaboration); information, media and technological skills (ICT literacy, media education).
And life and career skills (flexibility and adaptability, initiative and autonomy, social and intercultural skills, productivity, leadership and responsibility). It is also believed that technology can be used to reinforce interpersonal relationships between students and teachers, students and their parents and students with friends or colleagues.

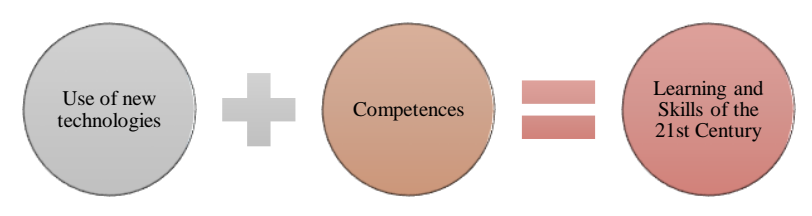

Figura 5 Conceptual framework of Learning and Skills of the 21st Century theory

Prepared by the authors

\section{Methodology and teaching strategies to develop}

In his book Towards a Dynamic General Didactics (1992), Nérici points out that the teaching methodology is a set of didactic procedures expressed by teaching methods and techniques, tending to bring to fruition the didactic action, which means achieving the objectives of teaching and, therefore, of education. On the other hand, the didactic strategy is understood as the planning of how the training process will be carried out; it includes a diagnosis of reality, the definition of objectives, the selection of didactic methods, tasks to be carried out and activities, resource planning and the form of the training process evaluation (Burgess and Russell, 2003; Cid-Sabucedo, Pérez-Abellás and Zabalza, 2009b; González and Ramírez, 2010). From the above, methodology in education is understood as a way to teach using didactic strategies that include techniques and methods to reach the ultimate goal: learning. Therefore, we suggest the following didactic methodology:

1. Identify by means of a written diagnostic test the previous knowledge or requirements for the subject in question. In the case of blind or visually impaired students, conduct an interview including questions that respond to the expected knowledge. In the same way, it is suggested to apply a Multiple Intelligences test with the intention of knowing the abilities or skills that the student has.

MOTA-BARRAGÁN, Martha Elba, MENDIOLA-GARCÍA, Yessica, MARTÍNEZ-AGUILAR, Gloria Mónica and MORALES-IBARRA, Vanessa Maribel. Analysis of learning theories for the creation of a methodology for inclusion in universities in Mexico. Journal-Republic of Colombia. 2019 
This will allow the choice of activities according to the existing abilities and intelligences of the students.

2. Carry out a group integration activity, in which, through personal questions such as interests, tastes, family and friends, students have the possibility to meet and generate empathy. From this activity it is important to observe the relationships and rapprochement of students with those with disabilities, so that the latter find support with one or more class members, that is, their tutor or tutors in the classroom who serve as support and assistance in case of doubt. It should be noted that this activity must be done in written form for deaf people.

3. Recognize the spaces and distribution of the classroom to place the student in the space that facilitates them to use their capacities in the most optimal way. Likewise, it is important to review with the coordination or administration the instruments, programs, tools and all the technological material available to define those that may be of continuous use, both for the teacher and the student. Nowadays, there are free programs or applications such as translators for Mexican Sign Language (MSL) that can facilitate the spontaneous use of vocabulary that listeners need to communicate with the deaf student. There are instruments such as screen checkers, magnified vision lenses, programs and applications for blind people and obviously Braille lines and printers.

4. Take into account the following recommendations:

a. In case of having a deaf student. The teacher should be in the front of the classroom, giving the student the opportunity to have complete vision of his face, hands and body, since there are students who, depending on the degree of deafness, can read lips or assign meaning to the intention of the message conveyed by the teacher through gestures and body movements. The teacher must write on the board or on any type of material clearly and precisely; also use visual media to achieve best understanding for the students with this disability. b. In case of having a visually impaired or blind student. The teacher must place the student in the part of the room where the acoustics favor them. These students have a more developed sense of hearing, so an explanation with a firm voice and good diction is necessary. It is also important that auditory materials such as recordings and videos are used, which can be recorded by the class. Likewise, it is advisable to have the materials in PDF files to provide them to students with this disability, since there are computer programs that narrate or describe this type of files to blind people, which is a very useful tool.

c. In case of having a student with motor disability. The teacher must take into account the type of disability of the student, that is, must answer the questions: Is the student paraplegic, quadriplegic? Does not have mobility in one of his limbs or both? Do they need help to make use of a wheelchair, crutches or walker? Do they need assistance in using the toilet? Once these questions are answered, the teacher will make the decisions regarding the activities that require mobility within the classroom or outside, also those in which the use of their limbs is required, in addition to finding the appropriate place within the classroom to facilitate access in case of having a wheelchair, crutches, etc.

\section{Results}

From the analysis of the characteristics of the suggested learning theories for the implementation of a methodology, it is intended that the teacher who faces the challenge of including a person with any of the disabilities mentioned in this work has a guide or starting point for the class.

It is expected that the teacher devotes part of the time it takes to prepare the classes, to apply the tests that will give them the required information about the student with disabilities, in order to subsequently carry out a didactic plan that facilitates classroom management. 
It is considered that, based on the best organization of the classroom as a learning environment and adequate teaching planning, students with disabilities have more confidence in the teaching staff, as well as their classmates, so that they are able to integrate into a group.

Therefore, it is expected that the dropout rate will be positively impacted if the students find a comfortable environment for their learning and do not feel left out, which sometimes lead them to dropout university temporarily or permanently.

In the last two years, we have analyzed the application of this methodology and students with disabilities who arrive at the Technological University of Torreón, therefore, it is expected to perform a qualitative analysis in the future with a case study, since it focuses on capturing the social reality of the and their development in their own context. This will be implemented in order to determine the necessary changes and adjustments to the proposal of this work and apply it in the different educational programs offered by the university.

\section{Acknowledgments}

In this section we recognize the Technological University of Torreón for the granted privilege of being teachers of students with disabilities. Likewise, we acknowledge the support provided for the implementation of this work, hoping to further examine this issue by conducting quantitative studies in order to contribute to teaching performance and promote Inclusive Education in Mexico.

\section{Conclusions}

Day by day, universities in Mexico have committed to include people with disabilities and allow them to have access to higher education in the classrooms, which shows progress in terms of the right to education. However, despite the existence of inclusive universities that have the instruments and materials to work with people with disabilities, there is no constant training for teachers. This could cause confusion, frustration, or simply lack of interest from both teachers and students.
For this reason, through the analysis of five learning theories, we suggest a simple methodology that allows the teacher to have a starting point when they receive a student in their classroom with any of the three disabilities mentioned in this analysis, which are: hearing, visual and motor disability. Although there are a variety of theories, we only consider the previous ones due to their characteristics and those of the disabilities in question. Using a methodology that acts as a starting guide, we hope that the teacher can have an idea of the type of explanations, activities, materials, monitoring, time and space to use when planning the classes and thus include students with disabilities.

By applying this methodology, qualitative studies can be subsequently carried out through a case study. In the same way, qualitative studies which focus on capturing the social reality of the study subject and the development in their own context can be enforced. All of the above in order to have data to ensure the benefits generated by the suggested methodology, and then apply it in different educational programs in various universities.

\section{References}

Armstrong, T. (2001). Inteligencias Múltiples: cómo descubrirlas y estimularlas en sus hijos. San José, Costa Rica: Grupo Editorial Norma.

Burgess, J. R. D. y Russell, J. E. A. (2003). The effectiveness of distance learning initiatives in organizations. Journal of Vocational Behavior, 63: 289-303.

Campbell, L., Campbell, B.,y Dickenson, D. (2002). Inteligencias múltiples. Usos prácticos para la enseñanza y el aprendizaje. Buenos Aires, Argentina: Editorial Troquel S. A.

Cid-Sabucedo, A., Pérez-Abellás, A. y Zabalza, M. A. (2009a). Las prácticas de enseñanza declaradas de los "Mejores Profesores" de la Universidad de Vigo. Relieve, 15 (2), 1-29. Available at http://www.uv.es/RELIEVE/v15n2/RELIEVEv 15n2_7.htm

Duarte, González y otros, (1988) Marco conceptual de la psicología cognitiva. Publicación interna de la Cátedra de Psicología General II, Facultad de Psicología, Universidad de Belgrano. Buenos Aires.

MOTA-BARRAGÁN, Martha Elba, MENDIOLA-GARCÍA, Yessica, MARTÍNEZ-AGUILAR, Gloria Mónica and MORALES-IBARRA, Vanessa Maribel. Analysis of learning theories for the creation of a methodology for inclusion in universities in Mexico. Journal-Republic of methodology for Colombia. 2019 
Durán, C. P. V. (2019). Metodología para la enseñanza de las Ciencias Naturales empleada por docentes costarricenses de las escuelas Vesta, Jabuy y Gavilán pertenecientes a la comunidad indígena Cabécar. Revista Educación, 451-467.

García, A. T., \& Reyes, T. I. M. (2019). El proceso de enseñanza, aprendizaje y el uso de las TIC en el nivel medio superior Administración y contabilidad conectadas en la vida de los adolescentes de preparatoria. Revista RedCA, 1(4), 111-126.

Gardner, H. (2001). La inteligencia reformulada. Las inteligencias múltiples en el siglo XXI. Barcelona, Spain: Ediciones Paidós.

González, M. G. y Ramírez, I. R. (2010). Enseñar a aprender, un reto para la formación de profesionales universitarios en el nuevo siglo. ODICEO, Revista Electrónica de Pedagogía, 7 (14), $1 . \quad$ Available at: http://www.odiseo.com.mx/bitacoraeducativa/ensenar-aprender-reto-paraformacion-profesionales-universitarios-nuevosiglo

Instituto de Tecnologías Educativas (2010), Habilidades y competencias del siglo XXI para los aprendices del nuevo milenio en los países de la OCDE (Organización para la Cooperación y Desarrollo Económicos). Publicado con el acuerdo de la OCDE, Paris.

Instituto Nacional de Estadística y Geografía (INEGI) (2010), Clasificación de Tipo de Discapacidad - Histórica. Mexico.

Santos, J. O. F. (2019). Análisis conceptual de las prácticas inclusivas en el aula, diversidad y convivencia escolar. Aibi revista de investigación, administración e ingeniería, 3640 .

León o y Montero, I (1995) Diseño de investigaciones. Introducción a la lógica de la investigación en psicología y educación. Madrid. McGraw-Hill, p. 39.

Lev S. Vygotsky, (1995) Pensamiento y lenguaje. Teoría del desarrollo cultural de las funciones psíquicas. Argentina: Ediciones Fausto.
Lion, C. (2017) Tecnologías y aprendizaje: claves para repensar la escuela. En. N. Montes. Comp. Educación y TIC. De las políticas a las aulas. Buenos Aires: EUDEBA.

Manning Lilianne, (1990) Neuropsicología cognitiva del lenguaje, Unidad de Neuropsicología del Radcliff Inrimery, Oxford.

Martínez Carazo, Piedad Cristina (2006) El método de estudio de caso: estrategia metodológica de la investigación científica Pensamiento \& Gestión, Universidad del Norte Barranquilla, Colombia, núm. 20, pp. 165-193

Parkin, A.J. (1999) Exploraciones en neuropsicología cognitiva. Madrid: Panamericana.

Piaget J. (1969) Psicología y Pedagogía. Barcelona: Ariel.

Reyes, J. G., Osorio, J. M. P., \& Rousell, H. B. A. (2019). Representaciones sociales sobre la persona con discapacidad de estudiantes de Nivel Superior en México. Revista Iberoamericana de Educación, 80(2), 129-150.

United States Department of Education, (2014) Partnership for 21st Century Skills, MacArthur Foundation. Available at: https://www.ed.gov/

Woolfolk, Anita, (1999) Psicología Educativa, Mexico. Prentice hall.

Zayas, C. G. S., Pérez, A. D., Peña, J. L. M., \& Cutiño, A. G. (2019). Estrategia Pedagógica para la formación ambiental de los estudiantes de Agronomía en el Centro Universitario Municipal de Guáimaro desde el modelo de universalización en Cuba. Revista de Investigación Académica Sin Frontera: División de Ciencias Económicas y Sociales, (29), 38-38. 